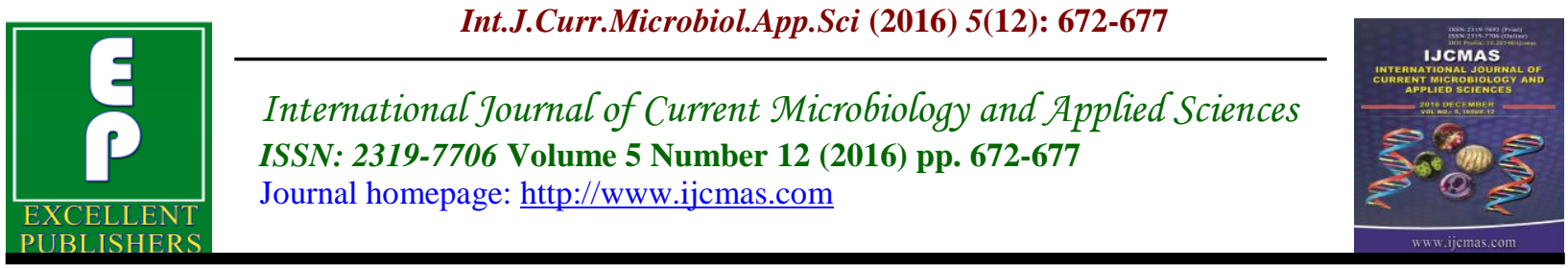

Original Research Article

http://dx.doi.org/10.20546/ijcmas.2016.512.075

\title{
Estimates of Genetic Variability, Heritability and Genetic Advance for Blast Resistance Gene Introgressed Segregating Population in Rice
}

\author{
Ponnaiah Govintharaj*, Shalini Tannidi, Manonmani Swaminathan \\ and Robin Sabariappan
}

Department of Plant Breeding and Genetics, Centre for Plant Breeding and Genetics, Tamil Nadu Agricultural University, Coimbatore-641003, Tamil Nadu, India

*Corresponding author

\begin{tabular}{|c|c|}
\hline & A B S T R A C T \\
\hline & \multirow{6}{*}{$\begin{array}{l}\text { A study was conducted to know the level and magnitude of genetic variability, } \\
\text { heritability and genetic advance of blast resistance gene introgressed segregating } \\
\text { population of three crosses in rice. High genotypic coefficient of variation (GCV) } \\
\text { and phenotypic coefficient of variation (PCV) was found in the cross CB } 174 \mathrm{R} \times \\
\text { Zenith ( } 22.02 \% \text { and } 23.12 \text { ) for the trait of number of productive tillers per plant. } \\
\text { This result indicated that selection of superior segregants could be utilized to } \\
\text { develop elite genotypes significantly. For single plant yield, CB } 174 \mathrm{R} \times \text { Zenith } \\
\text { cross was showed high heritability coupled with high genetic advance }(\%) \text { of mean } \\
(60.54 \% \text { and } 25.21 \%) \text { suggesting additive gene action under primarily controlled } \\
\text { and simple selection, moderate heritability conjugated with high genetic advance } \\
(50.46 \% \text { and } 24.19 \%) \text { was found in the cross of TNAU CMS } 2 \mathrm{~B} \times \text { Zenith } \\
\text { indicating that selection could be done at later generation, whereas in the cross CB } \\
87 \mathrm{R} \times \text { Zenith showed moderate heritability joined with moderate low genetic } \\
\text { advance as per cent of mean (58.99\% and } 6.41 \%) \text {, indicating that this trait was } \\
\text { governed by both additive and non-additive type of gene action and selection may } \\
\text { be effective. }\end{array}$} \\
\hline Keywords & \\
\hline $\begin{array}{l}\text { Genetic variability, } \\
\text { Heritability, } \\
\text { Genetic } \\
\text { advance, Rice. }\end{array}$ & \\
\hline Article Info & \\
\hline $\begin{array}{l}\text { Accepted: } \\
\text { 26 November } 2016 \\
\text { Available Online: } \\
\text { 10 December } 2016\end{array}$ & \\
\hline 10 December 2016 & \\
\hline
\end{tabular}

\section{Introduction}

Rice is one of the most important stable cereal food crop in India. The total rice production was estimated at 103.61 million tones during 2015-16 (Government of India, Ministry of Agriculture), which is low as 1.87 million tones as compared to the year 2014-15 production (105.48 million tones). Rice blast is caused by fungal pathogen (Pyricularia grisea), which cause severe yield loss upto $50 \%$ world-wide rice cultivable areas. (Scardaci et al., 1997;
Shalini et al., 2016). Genetic variability is an important, where parental selection for hybridization (Chaudhary and Singh, 1982) and crop improvement primarily depends on genetic variability in base population (Adebisi et al., 2001). Segregating populations are essence for improvement of plant traits by adopting various breeding technologies for further improvement. Among all, $F_{2}$ segregating generation has become more crucial and selection could be done meticulously. Prerequisite for any 
breeding programme is often requires genetic variability. Genetic parameter such as heritability offers the information of transmissibility of characters from one generation to consecutive generations (Bello et al., 2012). High heritability with high genetic advance (\%) of mean is used to predict the performance of genotype/progeny for yield and yield contributing traits (Singh et al., 2011; Govintharaj et al., 2016). Keeping view on these issues, the present study was aimed to know the variability, heritability and genetic advance for yield and yield contributing traits of blast introgressed segregating populations in rice.

\section{Materials and Methods}

Parental lines of released rice hybrids of CORH 3 (TNAU CMS 2A / CB 87R) and restorer line of TNAU rice hybrid $\mathrm{CORH} 4$ (COMS 23A / CB 174 R) used as recurrent parents. Zenith was used as resistant donor for blast resistance $\left(P i_{z}\right)$. Segregating progenies from blast introgressed three different $\mathrm{CB} 174 \mathrm{R} \times$ Zenith, $\mathrm{CB} 87 \mathrm{R} \times$ Zenith and TNAU CMS $2 \mathrm{~B} \times$ Zenith crosses were used in this study. The field experiment was carried out at Department of Rice, Tamil Nadu Agricultural University, Coimbatore in the growing season of 20122013. Single seedlings from each population were transplanted and spaced row to row and plant to plant distance of $20 \times 20 \mathrm{~cm}$. The standard agronomical practices were followed to grow healthy crop. Data was recorded from individual plants of each population for plant height $(\mathrm{cm})$, number of productive tillers per plant, panicle length $(\mathrm{cm})$, number of filled grains per panicle $(\mathrm{g})$, 1000 grain weight (g) and single plant yield (g). Data were subjected to standard statistical analysis such as variances were advocated as suggested by Johnson et al., (1955). Phenotypic and genotypic co- efficient of variation (PCV and GCV) were calculated as described by Johnson et al., (1955). Broad sense heritability was estimated as defined by Lush (1940). Genetic advance as per cent of mean was adopted according to the method of Johnson et al., (1955).

\section{Results and Discussions}

\section{Plant height}

Among three crosses of blast introgressed $\mathrm{F}_{2}$ population, highest amount of variability $(51.00-99.00 \mathrm{~cm})$ was found in TNAU CMS $2 \mathrm{~B} \times$ Zenith and the lowest range of variability $(87.50-109 \mathrm{~cm})$ in $\mathrm{CB} 87 \mathrm{R} \times$ Zenith (Table 1, 2 and 3). High heritability with moderate genetic advance $(\%)$ of mean was found in all the crosses $(93.64 \%$ and $13.05 \%$ ) CB $87 \mathrm{R} \times$ Zenith, TNAU CMS 2B $\times$ Zenith $(89.40 \%$ and $18.19 \%)$ and $(85.09 \%$ and $17.05 \%$ ) $\mathrm{CB} 174 \mathrm{R} \times$ Zenith, suggesting that an additive genetic component was prevalent and selection might be effective. This finding was get accordance with our results (Bekele et al., 2013; Kiani et al., 2013; Shrivastava et al., 2015; Govintharaj et al., 2016).

\section{Number of productive tillers}

Estimates of GCV and PCV were high and low for $\mathrm{CB} 174 \mathrm{R} \times$ Zenith $(22.02 \%$ and $23.12 \%)$ and $\mathrm{CB} 87 \mathrm{R} \times$ Zenith $(11.54 \%$ and $12.92 \%$ ), respectively. Higher GCV and PCV estimate offers wider scope of selection for elite segregants (Ameenal et al., 2016). Whereas, TNAU CMS 2B $\times$ Zenith cross combination was showed high PCV and low GCV (21.79\% and 5.06\%) due to environmental influences. Higher estimate heritability and genetic advance (\%) of mean was noticed for all studied crosses $\mathrm{CB} 87 \mathrm{R} \times$ Zenith $(79.88 \%$ and $21.25 \%), \mathrm{CB} 174 \mathrm{R} \times$ Zenith $(73.50 \%$ and 
40.83\%) and TNAU CMS 2B $\times$ Zenith $(69.90 \%$ and $27.79 \%)$ indicated that prevalence of additive type of gene action and selection could be done at initial stage. This finding gets supported with Kiran et al., 2012.

\section{Panicle length}

Moderate GCV and low PCV was exhibited in CB $174 \mathrm{R} \times$ Zenith. Moderate heritability and genetic advance as percent of mean was gained for CB $174 \mathrm{R} \times$ Zenith $(52.97 \%$ and $13.77 \%)$ and TNAU CMS 2B $\times$ Zenith $(57.52 \%$ and $13.28 \%)$ suggesting that selection could be effective on basis of desirable agronomical performance. This finding was line up with (Govintharaj et al., 2016). While for CB $87 \mathrm{R} \times$ Zenith $(51.13 \%$ and $9.90 \%)$ combination exposed moderate heritability accompanied with low genetic advance, indicating that selection would be difficult at early segregating generation (Mazid et al., 2013; Bitew, 2016; Govintharaj et al., 2016).

\section{Number of grains per panicle}

The wide range of variability was TNAU CMS 2B $\times$ Zenith (59.00-159.00nos) $>$ CB $174 \mathrm{R} \times$ Zenith (77.00-153.00nos) > (89.00131nos) CB $87 \mathrm{R} \times$ Zenith. Medium GCV and PCV were displayed for the combination of TNAU CMS 2B $\times$ Zenith $(17.17 \%$ and $18.96 \%)$ and CB $87 \mathrm{R} \times$ Zenith (13.05\% and $13.06 \%)$. Whereas, CB $174 \mathrm{R}$ $\times$ Zenith was exhibited low GCV and medium PCV (8.84\% and $13.15 \%)$. High heritability coupled with high genetic advance as per cent of mean was observed for the cross combination of CB $87 \mathrm{R} \times$ Zenith $(94.15 \%$ and $26.87 \%)$, TNAU CMS $2 \mathrm{~B} \times$ Zenith (89.55\% and $34.99 \%)$ and CB $174 \mathrm{R} \times$ Zenith $(83.98 \%$ and $24.82 \%)$, indicating that this character was little influenced by environment and accumulation of more additive genes highly amenable for simple selection. Similar results were line up with our findings (Singh et al., 2007; Sabesan et al., 2009; Govintharaj et al., 2016).

\section{Thousand grain weight}

GCV and PCV were medium for $(14.17 \%$ and $10.53 \%) \mathrm{CB} 174 \mathrm{R} \times$ Zenith and, while low GCV and medium PCV were observed in CB $87 \mathrm{R} \times$ Zenith $(7.09 \%$ and $10.22 \%)$ and $(4.93 \%$ and $12.54 \%)$ in TNAU CMS 2B $\times$ Zenith. Heritability and genetic advance as per cent of mean was high for TNAU CMS $2 \mathrm{~B} \times$ Zenith $(77.82 \%$ and $20.11 \%)$ signifying that additive genetic components preponderantly control and appropriate for straightforward selection. High heritability and medium genetic advance (\%) of mean was observed in $(68.27 \%$ and $10.14 \%) \mathrm{CB}$ $87 \mathrm{R} \times$ Zenith and $(72.68 \%$ and $18.49 \%) \mathrm{CB}$ $174 \mathrm{R} \times$ Zenith, indicating that this character was governed by additive gene action. This finding was corroborated with Tuwar et al., 2013; Govintharaj et al., 2016.

\section{Single plant yield}

High GCV and medium PCV was estimated in $(25.92 \%$ and $15.73 \%)$ CB $174 \mathrm{R} \times$ Zenith and, low GCV and PCV was estimated in CB $87 \mathrm{R} \times$ Zenith $(5.19 \%$ and $8.65 \%)$. Whereas the cross combination TNAU CMS 2B $\times$ Zenith (4.81\% and $23.28 \%)$ expressed low GCV and high PCV. High heritability and genetic advance (\%) of mean was observed in CB $174 \mathrm{R} \times$ Zenith $(60.54 \%$ and $25.21 \%$ ), suggesting that predominantly controlled by additive gene action and improvement of this trait through hybridization followed by pedigree breeding. This finding was corroborated with our reports (Gyanendra et al., 2011; Ahmad et al., 2015; Govintharaj et al., 2016). 
Table.1 Variability parameters in F2 population of the cross CB $174 \mathrm{R} \times$ Zenith for yield and yield contributing traits in rice

\begin{tabular}{ccccccccc}
\hline Characters & Range & Mean & $\begin{array}{c}\text { GV } \\
(\%)\end{array}$ & $\begin{array}{c}\text { PV } \\
(\%)\end{array}$ & $\begin{array}{c}\text { GCV } \\
(\%)\end{array}$ & $\begin{array}{c}\text { PCV } \\
(\%)\end{array}$ & $\begin{array}{c}\text { Heritability } \\
(\%)\end{array}$ & $\begin{array}{c}\text { GA of } \\
\text { mean } \\
(\%)\end{array}$ \\
\hline PH & $75.00-109.00$ & 94.74 & 73.65 & 86.56 & 10.00 & 8.97 & 85.09 & 17.05 \\
NPT & $5.00-7.00$ & 10.53 & 5.43 & 7.39 & 22.02 & 23.12 & 73.5 & 40.83 \\
PL & $15.00-29.00$ & 21.99 & 2.9 & 5.49 & 15.79 & 9.18 & 52.97 & 13.77 \\
NG & $77.00-153.00$ & 109.08 & 203.89 & 242.76 & 8.84 & 13.15 & 83.98 & 24.82 \\
1000GW & $12.60-22.30$ & 17.32 & 3.39 & 4.67 & 14.17 & 10.53 & 72.68 & 18.49 \\
SPY & $8.70-29.40$ & 18.21 & 9.21 & 15.21 & 25.92 & 15.73 & 60.54 & 25.21 \\
\hline
\end{tabular}

Note: PH: Plant height (cm), NPT: Number of productive tillers, PL: Panicle length $(\mathrm{cm})$, NG:

Number of grains per panicle, 1000GW: Thousand grain weight (g), SPY: Single plant yield (g).

Table. 2 Variability parameters in F2 population of the cross CB $87 \mathrm{R} \times$ Zenith for yield and yield contributing traits in rice

\begin{tabular}{ccccccccc}
\hline Characters & Range & Mean & $\begin{array}{c}\text { GV } \\
(\%)\end{array}$ & $\begin{array}{c}\text { PV } \\
(\%)\end{array}$ & $\begin{array}{c}\text { GCV } \\
(\%)\end{array}$ & $\begin{array}{c}\text { PCV } \\
(\%)\end{array}$ & $\begin{array}{c}\text { Heritability } \\
(\%)\end{array}$ & $\begin{array}{c}\text { GA of } \\
\text { mean } \\
(\%)\end{array}$ \\
\hline PH & $87.50-109.00$ & 97.11 & 42.86 & 48.54 & 6.74 & 7.17 & 93.64 & 13.05 \\
NPT & $8.00-23.00$ & 16.14 & 3.47 & 4.35 & 11.54 & 12.92 & 79.88 & 21.25 \\
PL & $16.50-26.50$ & 20.32 & 1.13 & 1.33 & 5.22 & 5.67 & 51.13 & 9.9 \\
NG & $89.00-131.00$ & 109.78 & 205.36 & 205.56 & 13.05 & 13.06 & 94.15 & 26.87 \\
$1000 G W$ & $18.38-26.78$ & 21.05 & 2.23 & 4.63 & 7.09 & 10.22 & 68.27 & 10.14 \\
SPY & $20.17-28.32$ & 22.88 & 1.41 & 3.92 & 5.19 & 8.65 & 58.99 & 6.41 \\
\hline
\end{tabular}

Note: PH: Plant height $(\mathrm{cm})$, NPT: Number of productive tillers, PL: Panicle length $(\mathrm{cm})$, NG:

Number of grains per panicle, 1000GW: Thousand grain weight (g), SPY: Single plant yield (g). 
Table.3 Variability parameters in F2 population of the cross TNAU CMS $2 \mathrm{~B} \times$ Zenith for yield and yield contributing traits in rice

\begin{tabular}{ccccccccc}
\hline Characters & Range & Mean & $\begin{array}{c}\text { GV } \\
(\%)\end{array}$ & $\begin{array}{c}\text { PV } \\
(\%)\end{array}$ & $\begin{array}{c}\text { GCV } \\
(\%)\end{array}$ & $\begin{array}{c}\text { PCV } \\
(\%)\end{array}$ & $\begin{array}{c}\text { Heritability } \\
(\%)\end{array}$ & $\begin{array}{c}\text { GA of } \\
\text { mean }(\%)\end{array}$ \\
\hline PH & $51.00-99.00$ & 77.73 & 52.72 & 58.97 & 8.23 & 9.88 & 89.4 & 18.19 \\
NPT & $4.00-20.00$ & 8.46 & 2.23 & 3.61 & 5.06 & 21.79 & 61.9 & 27.79 \\
PL & $17.00-27.00$ & 21.99 & 3.49 & 6.07 & 3.98 & 11.2 & 57.52 & 13.28 \\
NG & $59.00-159.00$ & 91.54 & 269.89 & 301.36 & 17.17 & 18.96 & 89.55 & 34.99 \\
$1000 G W$ & $12.16-26.60$ & 19.81 & 4.81 & 6.18 & 4.93 & 12.54 & 77.82 & 20.11 \\
SPY & $4.09-19.83$ & 8.46 & 1.96 & 3.88 & 4.81 & 23.28 & 50.46 & 24.19 \\
\hline
\end{tabular}

Note: PH: Plant height (cm), NPT: Number of productive tillers, PL: Panicle length $(\mathrm{cm})$, NG:

Number of grains per panicle, 1000GW: Thousand grain weight (g), SPY: Single plant yield (g).

Moderate heritability and high genetic advance was found in the cross combination of TNAU CMS $2 \mathrm{~B} \times$ Zenith $(50.46 \%$ and $24.19 \%)$. This result gets supported with Govintharaj et al., 2016. While, CB $87 \mathrm{R} \times$ Zenith showed moderate heritability and low genetic advance $(\%)$ of mean $(58.99 \%$ and $6.41 \%$ ), advised that difficulty in trait improvement at early generation.

In conclusion, the present study revealed that wide range of variability was available in almost all the studied characters. The characters like number of productive tillers, number of grains and single plant yield was showed high heritability combined high advance as per cent of mean. High heritability accompanied with high genetic advance (\%) of mean of blast introgressed segregants could be useful in future breeding programme.

\section{References}

Ahmad, F., Hanafi, M.M., Hakim, M.A., Rafii, M.Y., Arolu, I.W., Akmar Abdullah, S.N. 2015. Genetic Divergence and Heritability of 42 Coloured Upland Rice Genotypes (Oryza sativa) as Revealed by Microsatellites Marker and AgroMorphological Traits. PLoS ONE, 10(9):138246.

Ameenal, M., Shalini, T., Govintharaj, P., Manonmani, S. and Robin, S. 2016. Assessment of parental genetic variability in rice. Int. J. Agri. Sci., 8(54): 2917-2919.

Bekele, B.D., Rakhi, S., Naveen, G.K., Kundur P.J. and Shashidhar H.E. 2013. Estimation of genetic variability and correlation studies for grain zinc concentrations and yield related traits in selected rice (Oryza sativa L.) genotypes. Asian J. Exp. Biol. Sci., 4(3): 345-351.

Bello, O.B., Ige, S.A., Azeez, M.A., Afolabi, M.S., Abdulmaliq, S.Y., Mahamood, J. 2012. Heritability and Genetic Advance for Grain Yield and its Component Characters in Maize (Zea mays L.). Intl. J. Plant Res., 2: $138-145$.

Bitew, J.M. 2016. Estimation of Genetic parameters, Heritability and genetic advance for yield related traits in upland rice (Oryza sativa L. and Oryza glaberrima Steud) Genotypes in Northwestern Ethiopia. World Scientific News, 47: 340-350. 
Govintharaj, P., Shalini, T., Manonmani, S. and Robin, S. 2016. Genetic parameters studies on bacterial blight resistance genes introgressed segregating population in Rice. World Scientific News, 59: 85-96.

Gyanendrapal, Verma, O.P., Pratap, N., Kumar, M., Chaudhary, R.K. and Singh, K. 2011. Genetic variability, heritability and divergence studies in rice (Oryza sativa L.) under sodic soil. Environ. Ecol., 29:15971600.

Johnson, H.W., Robinson, H.F. and Comstock, R.E. 1955. Estimation of genteic and environmental variability in soyabean (Glycine max (L.) Merril.). Agron. J., 47(4): 314-318.

Kiani, G. 2013. Heritability and diversity analysis of quantitative traits in rice. Agriculturae Conspectus Scientificus, 78 (2) : 113-117.

Kiran, K. K., Gururaja Rao, M. R., Rajanna, M. P., Mohan Rao, A., Mahadevu, P. and Siddegowda, D. K. 2012. Variability, Heritability and Genetic Advance Studies in $\mathrm{F}_{2}$ Populations of Two Crosses of Rice (Oryza sativa L.). Mysore J. Agric, Sci., 46 (4): 917-919

Lush, J.L. 1940. Intra sire correlation and regression of offspring on dams as a method of estimating heritability of characters. Proc. Amer. Soc. Animal Production, 33(3): 293-301.

Mazid, M.S., Rafii M.Y., Hanafi M.M., Rahim H.A., Shabanimofrad M., Latif M.A. 2013. Agro-morphological characterization and assessment of variability, heritability, genetic advance and divergence in bacterial blight resistant rice genotypes. South
African J. Bot., 86:15-22.

Sabesan, T., Suresh, R. and Saravanan, K. 2009. Genetic Variability and Correlation for Yield and Grain Quality Characters of Rice Grown in Coastal Saline Low Land of Tamilnadu. Electronic J. Plant Breed, 1: 56-59.

Scardaci, S.C., Webster, R.K., Greer, C.A., Hill, J.E., William, J.F., Mutters, R.G., Brandon, D.M., McKenzie, K.S. and Oster, J.J. 1997. Rice blast: a new disease in California. Agronomy Fact Sheet Series. 2. Department of Agronomy and Range Science,University of California, Davis.

Shalini, T., Govintharaj, P., Ameenal, M., Manonmani, S. and Robin, S. 2016. Improving blast resistance in parental line of rice hybrid through marker assisted selection. Int. J. Agri. Sci. Res., 6(5): 339346.

Shrivastava, A., Mishra, D.K. and Koutu, G. K. 2015. Estimation of genetic parameters of variability for yield and its attributing traits in parental lines of hybrid rice. Plant Archives, 15 (1): 571-574.

Singh, M., Kumar, K. and Singh, R.P. 2007. Study of co-efficient of variation, heritability and genetic advance in hybrid rice. Oryza, 44(2):160-162.

Singh, S.K., Singh, C.M. and Lal, G.M. 2011. Assessment of Genetic Variability for Yield and its Component Characters in Rice (Oryza sativa L.). Res. Plant Biol., 1: 73-76.

Tuwar, A.K., Singh, S.K., Sharma, A. and Bhati, P.K. 2013. Appraisal of genetic variability for yield and its component characters in rice (Oryza sativa L.). Biolife, 1(3): 84-89.

\section{How to cite this article:}

Ponnaiah Govintharaj, Shalini Tannidi, Manonmani Swaminathan and Robin Sabariappan. 2016. Estimates of Genetic Variability, Heritability and Genetic Advance for Blast Resistance Gene Introgressed Segregating Population in Rice. Int.J.Curr.Microbiol.App.Sci. 5(12): 672677. doi: http://dx.doi.org/10.20546/ijcmas.2016.512.075 